A peer reviewed open access journal indexed in NepJol; ISSN 2542-2596

Published by Molung Foundation, Kathmandu, Nepal

Article History: Received on 18 February 2021; Accepted on 27 May 2021

DOI: $\underline{\text { https://doi.org/10.3126/mef.v11i0.37848 }}$

\title{
Bhada Tharu Homestay: Building National Integrity through Cultural Performance
}

\author{
Mohan Dangaura \\ Trinity College, Dillibazar, Kathmandu, Nepal
}

\section{Author Note}

Mr. Dangaura is a faculty at the Department of English, Trinity College, Dillibazar affiliated to Tribhuvan University, Nepal. He is currently pursuing an MPhil in English at Tribhuvan University. Email: mdangaura68@gmail.com 


\begin{abstract}
This article studies the challenges of modernity in Tharu people's way of life and how successfully they have sustained to maintain aesthetics of ethnicity coping together with modernity. The scholarly discussion of the impact of ritual performances of Tharu people to identify themselves in the national and international domain through the socio-cultural aspect of homestays provides us insight into how Tharus have become successful in preserving the memory of identity through cultural heritage. This study confines its approach within the Bhada village of Kailali district. It examines the progressive changes institutionalized after the homestay programmes in socio-cultural development of Tharu people's cultural performances facing urbanization. Homestay programmes in the Tharu village of Kailali district have accelerated their financial advancement chiefly by their exceptionally distinct social-cultural legacies of rituals and performances. With the assistance of various exploration reports, it essentially analyzes the part of social execution like dance melodies among Tharu people to bear the progressions for economic exercises and vocation. With the assistance of Devkota and Bhattarai's notion of homestays and rural development, the paper legitimizes the imminent practical development in the indigenous community by analyzing the issues from culture to modernity.

Keywords: homestay, Tharu-ritual performances, modernity, economy, development
\end{abstract}




\section{Bhada Tharu Homestay: Building National Integrity through Cultural Performance}

Bhada Tharu homestay has helped the financial and social execution of local people in the Kailali district of Nepal. With the appearance of homestay programs, local people have a chance to keep themselves occupied in the financial and social exhibitions. The absence of financial opportunities had previously caused them to choose more pay-producing monetary exercises within a short duration. The establishment of homestays has elevated the financial freedom of women, particularly those housewives who in the past were constrained to live with no income at all. Previously, they were reliant on their spouses and working individuals of their family. Almost 12.8 kilometers far from the Dhangadhi SubMetropolitan City, Bhada homestay lies with a Tharu majority, barring all other communities. On the occasion of tourism year 2011, Bhada homestay sarted on December 17 offering its local food and housing accommodation to visitors who had been unfamiliar with Tharu culture. Bhandari (2011) propels the promotion of rural tourism as the primary contributing factor for rural livelihood in Nepal. He write that 'The Tourism Policy 2065 BC Nepal' and 'Tourism Vision 2020 Nepal' have additionally tended to manage the tourism industry advancement by an emphasis on community based tourism and homestays. Bhandari asserts the launch of tourism programmes as the assisting factor in the economic change of rural parts of Nepal which were previously struggling to run the rural lifestyle.

Homestay is a provision in the convenient area that has seemed to address the issue of everyday tourism industry advancement. Rural tourism through homestays functions as a part of the eco- tourism industry that intends to construct the community folks' ability by truly investing local resources shrewdly and assists with securing climate change. Local tourism enables the folks to protect the natural surrounding where they reside. The forest area is protected by setting up community forest clubs. The riverside is developed as a tourist destination. 
The village roads are decorated by planting roadside gardens and trees. The waste products are managed in a proper and fixed place. Homestay makes them more conscious about preserving the serenity of their surroundings. The local ecosystem is transformed into a primitive landscape as best possible. Consequently it is recognized by professionals as an apparatus of sustainable development in the tourism industry. In the line to distinguish modern development as temporary and the need of eco-friendly modernization, Stabler and Goodall (1996) write that the idea of a sustainable tourism industry improves the fundamentals of modern development. They emphasize the propensity of rural tourism of homestay programmes with the more rational and emotional approach of modernity.

Sustainable tourism development expects to accomplish the equilibrium of effects to guarantee the quality of life of the host local area. Tosun (2011) believes in the preservation of indigenous culture and habitat with the establishment of homestay to socio-culturally distinct society. He suggests that homestay industry improvement ought to be arranged and administered for the insurance of the indigenous habitat for a group of people coordinating with economic sectors. It should regard the way of life and climate of the specific zone, its economy, and conventions. Homestay tourism needs to practice pre-work on the local traditions, socio-political approaches of the state, community demography, and financing.

The homestay makes its sightseers rejoice through different functions. Sakhiya, Jhumra, Maghauta, Lathauhwa, Baithakku, Mungrahuwa, Barki Maar, and Ghoruwa are mainstream society dance tunes of the Tharu. Common and man-caused scenes incorporate lakes, wild creatures, fowls, wildernesses, Behada baba sanctuary visits, Jagannath Bhuihar (Tharu Deuthan). Likewise, there are appealing wooden toys and materials reflecting conventional Tharu workmanship and day by day necessities dependent on agriculture. Bhalmansa Laxminarayan 
Tharu (L. Chaudhary, personal communication, December 12, 2020) explains about the accessibility of a wide range of Tharu food items alongside the chance of noticing and exploring Tharu culture, lifestyle, and customs in such homestays. Devkota (2008, as cited in Lama, 2013) states that in the nexus between tourism and economy homestay tourism is the microeconomic module in the inside part of the rustic zone along with uncovering the provincial culture and nature to the rest of the world. Homestay tourism enables the locals to generate income since they can sell their local products in the form of cuisine and crafts.

Tourists pay for facilities and comforts. Moreover, tourists also buy different handicrafts and embroidered dresses like the memento. This inspires the unemployed human resource to generate income from the microeconomic perspective. Absence of indigenous culture and heritage makes the government difficult for implementing policies. Button (1988) in his review of John Bodley's Tribal People and Development Issues reflects on the lack of clear understanding of the original features of the indigenous community in today's development policies. Button exposes the lack of state recognition and assimilation of indigenous culture and identity in the national integration. Government should invest adequate time and human resources to draft the scientific report on the cultural performances of the various tribes residing in the country. Tharu's cultural and ritual performances assist them to gain state recognition in the absence of proper state welfare programmes.

The government policies should not force these indigenous groups to change their way of life. If the groups feel they no longer can sustain living in the ritually accomplished lives, they avoid following the rituals strictly. Such policies may include the capitalist stream of the government. When the government prioritizes more to the individual growth over the business model, the indigenous group habitual to living in the larger community starts to segregate. Thus, the 
community cannot remain intact. Therefore, the economy can grow but the rituals fail. Such a situation can lead to inhuman treatment of each other.

The Tharu community has been subject to socio-political marginalization from the twentieth century when they were kamaiyas (bondage labour) exploited by the landlords. Their inclusion in the national development by recognizing their cultural heritage appears primary for national integration. In such conditions of extreme economic deprivation, they could hardly contribute to national development despite being a notable populace. Singh (2018) writes that in order to narrow the gap between the level of development of tribal areas and to improve the quality of the tribal communities, "elimination of all forms of exploitation particularly in land, money lending, and malpractices in the exchange of agricultural and forest products should be given high priority" (p. 822). He focuses on eliminating the social and economic gap between the hierarchies of classes by promoting such ethnic people more towards economic activities. Unless they become socially and politically active and realize their agency, the overall development of any state seems challenging.

\section{Objective and Methodology}

The primary objective of this paper is to explore the challenges of the poor economy in Tharu community and the secondary purpose is to recommend cultural performance as the innovative medium to enhance the economy. This study approaches the qualitative, descriptive method for the analysis of reports, data, and statistics comprising both primary and secondary sources. The secondary sources are based on journals, research articles on Tribal people, and challenges of the modern economy. Primary sources include statements archived from the field reporting. The arguments are validated from the research reviews conducted on the effects and benefits of homestay on promoting local tourism and microeconomics. Based on the phone interview and the online databases, the 
research provides the cultural performances as the promising perspective to empower women and unemployed youths.

\section{Tharu Community and Perspective of Development}

The Tharu community is bound by its own cultural norms and values. Different rituals performed throughout the year bring them under their own social discipline. Customs like Barghar, Bhalmansa, Hareri Puja, Hardahuwa and Kachhari create a system of local governance independent of modern bureaucracy in their community. Girase (2016) while explaining about the social system of the indigenous people states that the ethics, morals, norms and values are the components of controlling the social system in tribal life. Bhada homestay preserves the ethics and values of traditional Tharu folklore and performances.

Hechler (2003) presents a useful review of Guneratne's (2002) book Many Tongues, One People: The Making of Tharu Identity in Nepal that discusses the effects of modernity in shaping of Tharu identity. Guneratne seeks to demonstrate that the Tharu; a tribal group of the Nepal-India border area, derive their ethnic identity not from the past, but "from the conditions of modernity, the outcome of the organizing efforts of people whose life experiences are being transformed through modernization and state building" (Hechler, 2003, p. 983). He accuses the modern economic system behind the Tharu community's oblivion of their true cultural identity. In his study he shows how Tharus are struggling to cope with the liminality of modernity and tradition has obliterated many of their distinct cultures vital for signifying their identity. Following Imagined Communities by Benedict Anderson, Guneratne attempts to dispense with primordial explanations of ethnicity which hold in essence that contemporary ethnic identities are received more or less unchanged from premier past (Hechler, 2003). Guneratne establishes the issue of changing the lifestyle of Tharu. The identity of Tharu self and their involvement in development has accelerated much more quickly than in any other ethnicity. 
To develop and motivate Tharu community in national integration, special privileges over the natural resources around where they reside for domestic purposes should be allocated. They should be granted rights over the jungles, rivers and soil for sustenance farming. Vidyarthi (1972) advocates providing similar concessions and special privileges to tribes over the natural habitat around which they live. He writes, "The dependency of the tribal, whether forest dwellers or those whose economy is supplemented by forest produce is well-known" (p. 87). Tharus ought to be given a concession on assortment of deadwood for domestic use, minor forest produce for domestic utilization, the expulsion of lumbers, bamboos, reeds, jars, and so forth for development. The concession will help them to construct the houses and enhance farming.

Homestays provide proximity to the guests and the hosts. Since they are run by the owners of the respective houses, visitors feel adjacent to the behavior of hosts. They come to experience the dialogues and social communication skills of hosts. Visitors in Tharu homestays can connect themselves with the linguistic and communicative aspect of Tharu community. Sweeney (2008, as cited in Lynch, 2003) calls attention to such convenience where guests or visitors pay straightforwardly or in a roundabout way to remain in private homes, where connection happens to a more prominent or lesser degree with a host or potential family who typically live upon the premises. Visitors have an affluent time to get friendly with different aspects of Tharu life from food to folk songs. They can observe the rituals and recognize the particular customs. Sakhiya, Jhumra, Maghauta, Hurdangwa and Kathghori dances are performed on the arrival of national and international visitors. Different projects and programmes have been regularized for the promotion of such tourism throughout the district like organizing concerts and mahotsav (fairs), Maghi Milan programme and Barghar gathering. Bhada homestay with nearly 200 houses holds an immense prestige of cultural heritage and tourism. Jaand, rakshi, dhikri and bariya are among the 
popular food cuisines of Tharu culture. The Bhalmansa defines the celebration of Maghi as one of the most anticipated occasions for the locals and divine opportunity for the guests to get observed in the Tharu culture.

With 20 Tharu homestay houses in Bhada, internal and external visitors receive warm welcome in traditional Tharu reposes. The village, which is spread over an area of about 350 hectares and is surrounded by rivers, hills and forests, has a population of more than 1,700 at present. The community takes tourists in the Hellenic world of dance and songs in the evening after they are taken to watch the village culture on a day-long walk. The provision of basic hygiene, comfort and security has been well- looked after. Safe and comfortable sleeping room with bathroom and toilet are distinctly managed. The organized local tourist shuttle gorugada (oxen cart) takes the tourist to visit the famous religious and cultural tourist sites including Joginya Lake, Behada baba temple, Rameshwar temple, Sahadeva Mahdeva Lake, Koilihi Lake. Devkota (2008, as cited in Lama, 2013) describes the vivacity of such homestay programmes. He confers that homestay programmes can include a large range of performing activities for the visitors. Homestay combines provisions like adventure, trekking, social tourism, agro-tourism, pro-poor tourism, recreational tourism, and ecotourism. It builds every aspect of tourism contributing to the overall economy of the country.

Along with the glittering cultural performances and aromatic natural landscapes, Bhadagaun has an unusually strange myth related to its formation. The prevalent belief of the village as sacred to Tharu people only excludes nonTharus to permanently settle in the village. No other castes except Dangaura Tharus can live in the village. When talking about the myth, Bhalmansa clarifies that in ancient times, a Tharu Guru named Bhagauti Das 'Prakand' came through Dang's Hekunli and Bhaluwang and chose this independent place and settled in a forested area. Taking vow to the deity, he successfully established the small worshipping maruwa (temple) in the village. The recurrent examples of tales of 
non-Tharu dying or getting sick on attempting to live in this village permanently horrify the outsiders even up to now.

The establishment of the village as the Tharu homestay has brought positive changes to cope with the challenges of modernity after the former Urma VDC-8 of Kailali district got its political identity as Bhada. The Bhalmansa further said that drinking water, roads, electricity and other facilities were not available in the village earlier but nowadays those facilities have come to the fore. Since the connectivity from all directions is still a major problem basically from the west and north side, the need of making bridges over the river is urgent. He further puts the request to add a park, internet facility and daily transport facility to attract more tourists according to the modern demands of time. The minimum cost for the food and services are being charged for the promotion of culture along with the economic growth. As informed by the Bhalmansa, tourists interested in ethnic diversity and their research visit the homestay with immense expectation. He believes that the village has made a true gesture of hospitality under everyone's effort. Nearly 15000 to 20000 thousand incomes are being recorded as per the information provided by the Bhalmansa and the homestay operators.

\section{Culture and Economy: Micro-development through Homestay}

The government of Nepal attempts to help the provincial jobs by utilizing the country's normally rich resources and diverse culture to advance the tourism industry. There is no disbelief that homestay administrators earn by offering their own amenities to their visitors. Amran (2003, in Ibrahim \& Razzaq, 2011) writes that these exercises bring issues to apprehension on social trade and regard the host's way of life whereby vacationers can get appropriate accommodation with brilliant facilities. Homestay tourism can be run and promoted on a great scale especially in agricultural states. Lanier and Berman (1993, in Bhuiyan et al., 2011) also refer homestay venues as the programme which provides entertainment along with the economic income to supplement the locals with economic 
independence together with sense of cultural uniqueness. The homestay

environment creates a space for private families to become public by sharing their way of life to the visitor. Lynch (2003) discusses homestays programmes as the performance of the basic way of living of the host's customs and traditions. Bhada homestay functions as the ethnographical tool to analyze the everyday performance of Tharu community.

The tourists show interest in the local's cuisine and their unique cultural performances. The village houses are divided into different house numbers and if any tourist wants to stay for one and more nights, local house accommodation is available there. Since the place belongs to a humid region, rooms have been designed in a very comfortable way to let the air pass in the room. The cultural performance of women and men has been one of the major reasons for international tourists and social researchers to land on this ethnic land. Such performances have re-evolved the declining cultural activities and gaze in the rural atmosphere of Nepal. Since rural folks are more oriented towards the instant benefitting economic activities and are less occupied with the ideas of performing the traditional rites and rituals, Nepal as a single unique community is losing the grip of its originality. However, the inception of homestays has proved the aura of identity and resistance to inhuman modernity. The younger generations who hardly had any interest and motivation for cultural performances have been stirred through socialization with tourists. It has stimulated them to preserve cultural ingenuity.

The homestay programme developed in the distant and rustic regions enables locals to preserve their ecological zones. It helps them to protect ecologically vital woodlands, parks, cultural heritages, landmarks, and viewpoints. Bhuiyan et al. (2011) asserts the inclusive approach of homestays by transforming local areas into tourist destinations for recreation and receiving knowledge on local geographical features. Hawkins and Lamoureux (2001) 
implore about the combination of rich natural resources with the diversity of indigenous communities. Homestay programmes have provided immense growth of Nepal's originality and economic sustainability. Rivers (1998) characterizes homestay as a term that alludes to "guests leasing convenience from a nearby family to learn community culture, way of life, or language" (pp. 492-500). The authenticity of village life has been revoked through homestays. Bhada which was merely a village in the past and hardly known for its uniqueness has now been able to offer an epitome of Tharu cultural diversity and traditional museum sharing its vibrant lifestyles with all those living and visiting there.

\section{Women Empowerment through Homestay}

The homestay has immensely helped the domestically restricted women. Such women had no resource of income in the past. They were socially and economically victimized. With no source of income and communal involvement, women had a hard time to practice their skills for economic purposes and empower their social status. They suffered domestic torture and rarely had any decisive role in family. Men had no hope of being dependent on the women of their families prior to such programs. The turn of rural villages into tourist destinations empowered women by making them a prime part of cultural performances exhibited before visitors. They outdid their traditional roles from cooking, dressing, singing and dancing to subvert the patriarchy. Their cultural performances enable them to showcase the socializing strength of beauty. It attracts the visitors with the charm of their ornaments, dress, and bodies. Women can commiserate with the body as a power exercise.

By expelling all the futile and traditional concepts of being born into chains of social restrictions, the homestay has empowered Tharu women to calculate their potentials and concretize their decisions in families. Their cooking skills help them to create the entrepreneurship for marketing their local cuisines. Their limited space bound to the kitchen unexpectedly transgressed them from the 
boundary of the liminal space of the kitchen. Now, these women's participation in the folk dance songs has dismantled their submissive state and liminal space. Hence, it has gifted them the liberty of self-drive, self-decision, and selfsustainability. Ibrahim and Razzaq (2011) assert that the homestay programme makes sensations of solidarity locally while doing collaboration by keeping up the customary social qualities inside the local area. They further put the idea that the homestay programme improves the social union among individuals, reinforces authority and builds local area acknowledgment from the external world.

The involvement of these women has presented them as one of the prime members of the community's social and political performances. Tharu women are also viewed as the emblem of beauty due to their rich cultural dresses. Decorated in traditional clothes and ornaments, the audience views those as the object of the gaze. Along with this, even the sense of beauty gets interpreted in different forms. The cultural dress of these women comprises lehenga, embroidered blouse, earrings, necklace, rings, nose-rings, bracelets, payals, and other typical ornaments worn on different occasions. The vivid and vibrant dresses catch up not only with those archetypes of traditions but they too have defined them glamorously. Thapaliya et al. (2012) write that the ladies' gatherings and the adolescent gathering engage the visitor by playing out the social shows and serving delicious local food with the warm cordiality. The involvement of women in homestay programmes has worked as one of the major contributing factors to allure the visitors. Thus, the homestay functions as the platform to generate income by transforming the Tharu culture and women as the art to be observed and praised. Had there been no such cultural performance, hardly any visitor would have reflected any interest to visit them.

The display of dresses during folk dance performances has inevitably established the link between the beauties with tradition. The traditional performances of these dances are the medium to cohere the emotions and 
statement of empowerment through their bodies in the modernity that hardly accepts the uniqueness of women's body performances. It has even deconstructed the age-old sentiments of Tharu women merely as the object of beauty.

Moreover, it has strengthened and transformed that beauty into the subjective weapon to slay the oppression of patriarchy. The traditional concept of women in the Tharu community from the object of gaze contradicts the concept of submission and subjugation. On demanding the modern interpretation of the diversifying myth and projection of lehenga, the same women at present are being accepted as the standards of beauty. The orientation from the object of marginalization into the object of popular culture helps to reinterpret the flawed definition of women's dress. The derogatory thought of considering women just as an object of gaze justifies hypocrisy of the idealistic notion of society. The predestination of culture into beauty has re-established beauty as the empowering body. The homestay has empowered women's subjectivity. Moreover, it has enabled them to be financially independent and realize the importance of their integration into national development.

Homestay hosts advertise the destination describing its surroundings and location where the other important socio-cultural marks are situated. Local temples, lakes and forest reserves and popular tourist spots are a few of them. Bhuiyan et al. (2011) similarly assess that the local folks and homestay administrators attract the travelers by planting trees, securing the normal assets and customary culture by practicing eco-friendly waste management. Tharu folks know the significance of the forest that offers them the water, lumber, wood, and grass. The rural folks of Bhada worship natural resources as deities to bless them with continuous bliss and flow of nature's flow.

The ecosphere of a village has enriched the beauty of the homestays. The natural location of Bhada Tharu homestay surrounded by the jungles and rivers from its all side has aggrandized its beauty. Thapaliya et al. (2012) emphasize the 
beauty of the host destination which looks perfect with its greenery so that it attracts the sightseers to visit the place. The lush green vegetation surrounding the almost two hundred houses in typical traditional archetype has established the authenticity of Tharu community and culture in Bhada. The local pets; hens, pigs, goats, and fish items are also available for tourists to relish the delicious ethnic cuisine. Besides the beautiful natural surroundings, the concept of nature and people living in a single amalgamation has valued ecological balance which in turn protects the clean and green environment in order to to achieve sustainable development goals.

The villagers use firewood to cook the food and other daily cuisine obtained from the nearby jungle. However, there is an established pattern of extracting the resources from the community forest. The basic and waste going forest produces strictly excluding green trees and green vegetation are allowed to be collected once in three months. In the past farmers used to go hunting. There were no such strict laws and other state regulations but nowadays locals themselves have become environment conscious and have realized the importance of ecology as put forward by the village Bhalmansa.

Remaining intact with the agrarian lifestyle, the rituals and customs celebrated and performed remain in close relationship with farmers' way of life on and off the field. The dance songs like Sakhiya, Jhumra, Murdunghuwa, Laththahuwa reflect the embeddedness of non-humans and humans. The season of farming does not commence without performing Sakhiya dance preceded by Lwangi (first prayer for good harvest) puja to their ancestral deity. Similarly, after the completion of every planting and harvesting season, Jhumra is performed to mark the happiness of successful planting and harvesting. The ritual and cultural performances get intact in symmetrical alliance with each other. The singing of the elders and the involvement of young ones during the cultural performances manages to bridge the understanding and sharing of tradition through the 
exhibition of shared experiences. The young girls and young boys participating in the dances and songs create the agrarian romance and rural proximity amidst the gender differentiations. The romantic and cultural integration of the binary genders through the joyous performances works as one of the important procedures for building the adulthood of Tharu youths.

Devkota (2008, as cited in Lama, 2013) explains that the homestay programme contributes significantly for the support of working-class people in Nepal. The ritual of worshipping pagan deities by assimilating ancestral spirits into one's body by the Tharu youths has been the primary performance contributing to the gaze for the spectators. Piercing the body parts like tongue and hands after summoning the ancestral deity creates awe and sublimity to all the visitors coming to enjoy the economically and socially marginalized class. The shamanic performances function as the vital cultural lifestyles of the Tharu community. The regulation of day to day life and the incorporation of spiritual power has classified society as the epitome of deeply philosophical community. Tharu rituals are the major attraction for tourists. Tourists arrive at homestays to study the distinct Tharu rituals. This promotes cultural tourism that attracts investments from national and international levels to preserve and conduct research on their rituals. The rituals signify the voice of the community. The performances bring them to the observer and establish the Tharu community as one of the prominent communities of Nepal. The recognition helps them to seek the justice of being marginalized in the mainstream.

Such rituals become extremely important for researchers and scholars for the interpretation of diverse ethnicities. Thus, this homestay has simultaneously been performed as the anthropological library while being a sort of commercial enterprise. Visitors can study and approach the cultural significance. They can ultimately contribute more to the vivacity of ethnic promotion and sustainable development of the country. 


\section{Ethnicity, Identity, and Ecology}

Ethnicity has put together a lot of challenges to the developmental aspect of Tharu community. The inadequate representation in the national mainstream has undermined their capacity and social performances. The low income and scarce involvement in the alluring economic activities and bureaucratic posts have created major problems for the socio-economic growth of the ethnicity.

Overcoming the challenges, home stay tourism has provided an outlet to this community in national and international forums. Basumatary (2020) declares that government strategies and plans should orient towards inclusion of indigenous groups to national integration. Regardless, these courses of action and plans have not yet reached the needed goal. The standard culture and practices of ethnic people are impacted by non-tribal. She further strengthens her argument by showing the association between rich social traditions and nature. The interconnectedness of human culture and nature helps to understand the primary way of life.

Tharu identity has a deep-ecological relation with nature. Their tenderness to nature isolates them from other social groups. The need to develop the ethnic cultural lifestyle has become a present necessity. They equally contribute to the socio-economic development of the nation. However, if they remain neglected by the state policies as they used to be in the past, they will never be integrated in the national development. Their knowledge of organic farming and herbal medicines could be exploited largely with efficient policy and capital investment. They have to participate in socio-economic and political fields for local and national development. Homestay has brought them in the position to realize their ignorance. Homestay involvement has taught them to assimilate their backwardness to connect themselves for the overall national development. Few initiatives could be taken for enhancing the rural folks' status. Basumatary (2020) further explains such measures as establishing facilities of education, 
financial institutions, entrepreneurship skill training, and training on various skills like horticulture, animal husbandry, forestry, cottage and small scale industries. The problems aroused during the process of national integration should be tackled sensitively since initially indigenous people may not comprehend the change. Ethnicity includes a set of cultures, especially entwined with nature. It benefits to save nature for productive use in the future. However, it simultaneously needs tremendous government support for development. Regardless, if people are not dynamic, discerning, and secure in their other improvement, all implantation of government plans will be paltry. Therefore, the Tharu community should realize the necessity of their co-operation for sustainable national progress and harmonious integration.

Homestay scholar Sharma (2012) indicates the absence of managerial skills among the technically illiterate folks. He stresses the need for such homestay skill development training through the experts of hospitality management. Bhattarai (2012, as cited in Lama, 2013) clarifies about the tourism board's effort to diversify and commercialize the homestay programmes by coordinating the project with different travel and tour operators. Social gathering during the cultural performance provides the folks of the respective community to assimilate and learn the skills more authentically. Sedai (2006) exploring the scope of such gatherings writes that assortments of the caste and ethnic gathering acquire various shades of social customs. Their feasts and festivities are remarkable structures forming the bond of unity and identity. Ibrahim and Razzaq (2011) expose the added benefit about homestays even to the hosts as they have the opportunity to be familiar with foreign cultures shared by their visitors. It even revives their monotonous life by making them become acquainted with each other. At the point when the vacationers arrive at the homestays, they will locate a warm customary greeting from all the homestay hosts in their social dress and it 
assists with causing the traveler to feel revived. They took the visitor to the local area office for the reward and different campaigns.

Bhada Tharu homestay yields the opportunity to see, offer and feel the distinctly interesting Tharu life, culture, and custom. Bhada Tharu homestay shares the novel idea of tourism alongside local area advancement. It propels the commonplace economy through the progression of provincial tourism. Bhada homestay bounces the chance to local youths and women to generate income through the nearby resources. From the local way of life, food, dress, dance tunes to the naturally rich climate, Bhada arises as the credible Tharu character of western Nepal. Tharu, being a politically underestimated class, recovered their fortitude with Nepal's national integration through homestay programmes. The popular social exhibitions pictured among the public and international scholars set forth their cultural richness into the global society. The move of social exhibitions into income-creating exercises connects their identity with innovative cultural fertility. The sustenance of their culture and tradition with the advent of homestay provides them a silent resilience of ill-development and cultural appropriation comprehending the secular integration.

Bhada homestay has thus provided the Tharu community an important outlet to escape the economic dead zone. When they had unfruitful economic activities and a lack of innovations to regulate their economy, the concept of homestay emerged as the medium to generate employment for them together making them aware of global culture. The homestay has terminated their vacant times by engaging them in economic activities through the approaches like running guest houses, bars, cafes, continental stores, different cloth shops, tea stalls. It has also made them aware of the importance of education since they encounter local and international intellectuals. The folks have realized that their community's better future and the justice for rights can only be comprehended by 
making themselves economically as strong as they can and their children literate as much as it is possible.

Therefore the paper concludes by examining the difficulties of innovation in Tharu individuals' lifestyle and how effectively they have supported to keep up the style of nationality adapting together to modernity. The academic conversation of the effect of ceremonial exhibitions of Tharu individuals to recognize themselves in the public and global area through the socio-cultural part of homestays gives us insight into how Tharus have been trying to save the memory of identity through cultural legacy. Homestay programmes in Bhada of Kailali have sped up their economic progression mostly by their extraordinarily distinct social-cultural traditions of ceremonies and exhibitions. Basically, with the help of different research scholars, the paper has justified folk rituals of the Tharu community as the medium of their socio-economic progress. Beside this, the paper attempts to validate the community as the eco-lover who dwells and protects the natural resources of their locality helping to promote ecological conservation. The paper has incessantly focused on Tharu ethnicity and their folk rituals as the emblem of identity struggle. The identity exhibitions have been worked out through much democratic and systematic tourism of homestays. Therefore, homestays have not only incorporated the community into national development but it has also promoted their ethnicity, and culture as well. 


\section{References}

Basumatary, M. (2020). Issue, challenge and development problems in socio, economic and culture of tribal people in Assam. International Journal of Recent Technology and Engineering, 8 (5), 5222-5224. https://doi.org/ 10.35940/ijrte.D9226.018520

Bhandari, K. R. (2011). Tourism policies and priorities, research, planning and monitoring. Nepal Tourism Board. https://webunwto.s3.eu-west1.amazonaws.com/imported_images/29016/country_report_nepal.pdf

Bhuiyan, M. A. H., Siwar, C., Ismail, S. M., \& Islam, R. (2011). The role of home stay for ecotourism development in East Coast economic region. American Journal of Applied Sciences, 8(6), 540-546. https://doi.org/10.3844/ajassp.2011.540.546

Button, G. (1988). [Review of the book Tribal Peoples and Development Issues: A Global Overview, by J. Bodley]. APLA Newsletter, 11(1), 12-15. http://www.jstor.org/stable/24499087

Girase, S. (2016). The problems of Indian tribal communities in current scenario. International Journal of Development Research, 6(5), 7924-7927. https:/www.journalijdr.com/sites/default/files/issue-pdf/5356.pdf

Hawkins, D., \& Lamoureux, K. (2001). Global growth and magnitude of ecotourism. In Weaver, D.B. (Ed.), The encyclopedia of ecotourism (6372). CABI Publishing. https://doi.org/10.1079/9780851993683.0063

Hechler, W. (2003). Review of the book Many Tongues, One People: The Making of Tharu Identity in Nepal, by Arjun Guneratne. Cornell University Press. The Journal of Asian Studies, 62 (3), 983-984. https://doi.org/10.2307/3591908

Ibrahim, Y., \& Razzaq, A. R. A. (2011). Homestay program and rural community development in Malaysia. Journal of Ritsumeikan Social Sciences and 
Humanities, 2(1), 7-24. http://www.ritsumei.ac.jp/acd/re/krsc/hss/book/pdf/vol02_03.pdf

Lama, M. (2013). Community homestay programmes as a form of sustainable tourism development in Nepal [Unpublished master's thesis]. Centeria University of Applied Sciences.

https://www.theseus.fi/bitstream/handle/10024/68913/COMMUNITY\%20 HOMESTAY\%20PROGRAMMES\%20AS\%20A\%20FORM\%20OF\%20 SUSTAINABLE\%20TOURISM\%20DEVELOPMENT\%20IN\%20NEPA L.pdf? sequence $=1$

Lynch, P. (2003). Resource guide: Homestay accommodation sector. LTSN hospitality, leisure, sport and tourism, 1. http://www.heacademy.ac.uk/assets/hlst/documents/resource_guides/home stay_a ccomodation_sector

Rivers, W. P. (2008). Is being there enough? The effects of homestay placements on language gain during study abroad. Foreign Language Annals. 31. 492500. https://doi.org/10.1111/j.1944-9720.1998.tb00594.X

Sedai, R. C. (2006). Accessing the sustainability of tourism in rural areas: A case study of Tamang heritage trail, Rasuwa [Unpublished master's thesis]. Purbanchal University. http://lib.icimod.org/record/12665/files/722.pdf

Sharma, P. (2012, October 2). Prospects and challenges of homestay in Nepal [Workshop session]. https://www.academia.edu/6800362/Home_Stay_Tourism_in_Nepal_Opp ortunities and Challenges

Singh, R. (2018). Tribal area development programmes in India: Issues and challenges. International Journal of Research in Social Science, 8(4), 827835.

https://www.ijmra.us/project\%20doc/2018/IJRSS_APRIL2018/IJMRA13697.pdf 
Stabler, M.J., \& Goodall, B. (1996). Environmental auditing in planning for sustainable island tourism. In L. Briguglio, B. Archer, J. Jafari, \& G. Wall, (Eds.), Sustainable tourism in islands and small states: Issues and policies (pp. 170-196). Pinter Publishers.

https://www.um.edu.mt/library/oar/handle/123456789/41070

Thapaliya, M., Rai, G., Shrestha, A., Parajuli, B., \& Pande, O. (2013). Home-stay: Assessment in Lwang Ghalel. Nepal Tourism and Development Review, 2(1), 105-140. https://doi.org/10.3126/ntdr.v2i1.7382

Tosun, C. (2001). Challenges of sustainable tourism development in the developing world: The case of Turkey. Tourism Management, 22(3), 289303. https://doi.org/10.1016/S0261-5177(00)00060-1

Vidyarthi, L. (1972). Problems and prospects of tribal development in India. Indian Anthropologist, 2(2), 80-93. http://www.jstor.org/stable/41919217 